\title{
CAN THEISTS AVOID \\ EPISTEMOLOGICAL OBJECTIONS TO MORAL (AND NORMATIVE) REALISM?
}

\author{
Justin Morton
}

\begin{abstract}
Epistemological objections to moral realism allege that realism entails moral skepticism. Many philosophers have assumed that theistic moral realists can easily avoid such objections. In this article, I argue that things are not so easy: theists run the risk of violating an important constraint on replies to epistemological objections, according to which replies to such objections may not rely on substantive moral claims of a certain kind. Yet after presenting this challenge, I then argue that theists can meet it, successfully replying to the objections without relying on the problematic kinds of substantive moral claims. Theists have a distinctive and plausible reply to epistemological objections to moral (and, in fact, normative) realism.
\end{abstract}

\section{Introduction}

Many epistemological objections to moral realism allege that realism entails moral skepticism. While it's unclear whether such objections work against non-theistic moral realists, many philosophers seem to think that theistic realists have an obvious escape route: if God exists, there is clearly no epistemological obstacle to moral realism. Yet because this is taken as so obvious, such suggestions are crucially underdeveloped. In this paper, I have two main purposes. First, I want to show that things are not so simple. There is a good case to be made that any plausible theistic reply to these objections begs the question by relying on a substantive moral claim when our knowledge of such is precisely what is in question. My second purpose is to show how the theist can plausibly answer this challenge: she can argue, without relying on any substantive moral claims of the kind targeted by such objections, that God brought about our moral knowledge. And, what's more, this answer also works in reply to epistemological objections to normative realism more broadly: it doesn't rely on the kind of normative belief targeted by such objections. I conclude that, while the theist does have a distinctive reply to epistemological objections, it is both far from obvious and very different from what many assume it would look like.

In §1, I lay out several different epistemological objections to moral realism before outlining one in more detail-an evolutionary debunking 
argument-so that I might rely on it as a test case. In §2, I review several philosophers' claims that theistic moral realism enjoys immunity from such epistemological objections. I then outline what I think is a natural case to be made for these claims. Then, in §3, I issue a challenge for this "natural reply": it seems to violate the requirement (which I defend) that replies to the evolutionary debunking argument not rely on a substantive moral claim. In $\S 4$, I issue a challenge for the theistic moral realist: she must argue that God has most normative reason to bring about our moral knowledge. In $\S 5$, I show two ways in which the theist might meet this challenge. Finally, in $\S 6$, I argue that both responses also work in reply to epistemological objections to normative realism more broadly.

\section{Epistemological Objections to Moral Realism}

Moral realism is the thesis that (i) sincere moral judgments express beliefs, (ii) some of those beliefs are true, and (iii) the truth of some moral beliefs does not constitutively depend on the attitude of any actual or hypothetical agent. ${ }^{1}$ Many epistemological objections to moral realism have it that realism entails moral skepticism. Yet different objections have it that this entailment holds because of different constraints on knowledge-constraints that, if realism were true, we purportedly could not meet. In this section, I'll briefly summarize a number of these general epistemological objections to moral realism, before going on to develop one at greater length. This last argument will be a test case for many of the claims I make about theistic moral realism in this paper.

Some think that to know something we must believe it by means of a non-accidentally reliable method and that moral realism fails this constraint: ${ }^{2}$

No Accident

1. To know that $\mathrm{P}, \mathrm{S}$ must believe that $\mathrm{P}$ by means of a non-accidentally reliable method.

2. If moral realism is true, then no agent believes any substantive moral claim by means of a non-accidentally reliable method.

3. Therefore, if moral realism is true, then no agent has any substantive moral knowledge.

By "substantive moral knowledge," I mean knowledge of a substantive moral claim. ${ }^{3}$ What makes a moral claim substantive is hard to say: "Discrimination on the basis of race is bad" is substantive; "Either Bob's discrimination was bad or it's not the case that it was bad" is not. We don't $3-4$.

'See, e.g., Shafer-Landau, "Evolutionary Debunking," 1; Enoch, Taking Morality Seriously,

${ }^{2}$ See Setiya, Knowing Right From Wrong, ch 3. For non-accidentality as a general constraint on knowledge, see Unger, "An Analysis of Factual Knowledge."

${ }^{3}$ The "substantive" qualifier isn't always included, but it should be. No matter the nature of moral facts, we could have knowledge of analytic moral claims. 
need a precise definition: debunkers are targeting knowledge of claims like the first example, but not the second.

Many others worry that if realism is true, it would be an unexplained coincidence if our moral faculties were reliable: ${ }^{4}$

\section{No Coincidence}

4. To know that $\mathrm{P}$, it must not be an unexplained coincidence that the faculties that produce S's belief that $\mathrm{P}$ are reliable.

5. If moral realism is true, then it would be an unexplained coincidence if any agent's moral faculties (at least those that produce substantive moral beliefs) were reliable.

6. Therefore, if moral realism is true, then no agent has any substantive moral knowledge.

Two other objections to moral realism can be grouped together. According to the first, if realism is true, then in the nearest possible worlds in which our moral beliefs are false, we still have those beliefs-i.e., they are insensitive: ${ }^{5}$

\section{Sensitivity}

7. If for some belief that $\mathrm{P}, \mathrm{S}$ believes that $\mathrm{P}$ in the nearest possible worlds in which not-P, then $S$ does not know that $P$.

8. If moral realism is true, then all agents would have the substantive moral beliefs they actually do in the nearest possible worlds in which those beliefs are false.

9. Therefore, if moral realism is true, then no agent has any substantive moral knowledge.

According to another objection, moral realism entails that in most of the near-by possible worlds in which we have the moral beliefs we do, our moral beliefs are false-i.e., they are unsafe: ${ }^{6}$

\section{Safety}

10. If for some belief that $\mathrm{P}, \mathrm{P}$ is false in most of the near-by possible worlds in which $\mathrm{S}$ believes that $\mathrm{P}$, then $\mathrm{S}$ does not know that $\mathrm{P}$.

\footnotetext{
${ }^{4}$ Street, "Darwinian Dilemma" and Street, "Reply to Copp." See also Bedke, "Intuitive Non-Naturalism"; Shafer-Landau, "Evolutionary Debunking"; and Parfit, On What Matters, 492-497. Finally, for presentation of a similar argument, see Enoch, Taking Morality Seriously, ch. 7 (esp. 7.2 ).

${ }^{5}$ Bedke, "Intuitive Non-Naturalism"; Clarke-Doane, "Morality and Mathematics"; and Kahane, "Evolutionary Debunking Arguments." See also Joyce, The Myth of Morality, 163-165 and Street, "Darwinian Dilemma," 125-126, especially n26. For a very similar way of formulating sensitivity (and safety), see, e.g., Pritchard, "Sensitivity, Safety, and Anti-Luck Epistemology."

${ }^{6}$ See Ruse and Wilson, "The Evolution of Ethics"; Joyce, The Evolution of Morality, 181; Street, "Darwinian Dilemma," 120-121; and even Darwin, The Descent of Man, 102. See also Bogardus, "Only All Naturalists."
} 
11. If moral realism is true, then all agents' substantive moral beliefs are false in most of the near-by possible worlds in which they have those beliefs.

12. Therefore, if moral realism is true, then no agent has any substantive moral knowledge.

There will be further details and problems for each of these four arguments, but such will be irrelevant here.

One might wonder what it is particularly about realism that generates these worries. That is, why does realism make it the case that (for example) no agent believes any substantive moral claim by means of a non-accidentally reliable method, and so on for the other constraints on knowledge? There is no helpful answer available at this point in the dialectic since the second premise of each argument could be supported in a number of different ways. However, it will be helpful to see one important way these premises have recently been supported. To this I now turn.

Though they are inherently more general in scope, most of these objections have recently been made in a very particular form. That is, each has it that if realism is true, then our moral beliefs fail some particular necessary condition on knowledge. But many philosophers have argued that it is the influence of evolution on our moral beliefs that results in the failure of that necessary condition. ${ }^{7}$ For most of the rest of my paper, I deal exclusively with such evolutionary debunking arguments (EDAs). I do this primarily just in order to have a single test case. But EDAs are an especially good test case for claims about the more general objections since for any of those objections there is an EDA that is a particular version of it. For these reasons, let us turn now to consider what I call the Standard EDA:

\section{The Standard EDA}

13. (Epistemological Premise) If (a) moral realism is true, (b) evolution has strongly influenced our moral faculties in such a way that those faculties are disposed to produce beliefs with certain propositional contents over others, and (c) there is no independent confirmation of the reliability of those faculties, then we have no substantive moral knowledge.

14. (Empirical Premise) Evolution has strongly influenced our moral faculties in such a way that those faculties are disposed to produce beliefs with certain propositional contents over others.

15. (Autonomy) There is no independent confirmation of the reliability of our moral faculties.

\footnotetext{
${ }^{7}$ See Street, "Darwinian Dilemma"; Gibbard, Thinking How to Live, ch. 13; and Joyce, The Evolution of Morality. See also Horn, "Evolution and the Epistemological Challenge"; Greene, "Secret Joke"; Kitcher, "Biology and Ethics"; and Ruse and Wilson, "Moral Philosophy as Applied Science."
} 
16. Therefore, if moral realism is true, then we have no substantive moral knowledge. ${ }^{8}$

Let's briefly look at the premises in more detail.

Premise (14) is not my concern here, since theism generally does nothing to aid a denial of evolutionary influence on our moral faculties. ${ }^{9}$ Perhaps theists have a special purchase on denials of evolution altogether-but I will make my task easier by only considering types of theism which are compatible with evolutionary biology. Premise (15) will end up being the theist's target. But before moving on to see whether she can hit that target, let's get a quick look at how the standard debunker could support (13).

It is (13) where the four general epistemological objections above come into play. As one example, consider:

Sensitivity $_{E D A}$

17. If (a)-(c) hold, then we would still have our moral beliefs in the nearest possible worlds in which they are false.

18. If we would believe that $P$ in the nearest possible worlds in which $P$ is false, then we do not know that $P$.

19. Therefore, if (a)-(c) hold, then we have no substantive moral knowledge.

(18) simply represents the general constraint on knowledge mentioned originally in premise (7) of Sensitivity. The other constraints could (and have) played similar roles in defense of (13).

But what about (17)? What is it about realism that generates the worry that our moral beliefs are insensitive (when assuming evolutionary pressure and no independent confirmation)? Roughly, the worry is that my belief that I ought to take care of my children is adaptive regardless of whether it is true: believing it makes us more likely to pass on our genetic material even if it is false. (Compare to the perceptual case: it is usually only adaptive to believe that there is a tiger nearby if there actually is.) Thus, in the nearest worlds in which this claim is false, we still believe it.

Anti-realists don't face the same fate. Take the (toy) anti-realist view that an act is wrong iff-and wholly because-I believe that it is wrong. On this view, supposing that it is true that I ought to take care of my children, this is only true because I believe that it is true. Where it is false, I do not believe that it is true-as a direct result of the theory. So, in the nearest worlds in which it is false, I do not believe it.

${ }^{8}$ This argument is meant to capture what is common to the EDAs cited in $n .7$ above in the most charitable way possible.

${ }^{9}$ Critics of (14) include Shafer-Landau, "Evolutionary Debunking," 5-8; Fitzpatrick, "No Darwinian Dilemma," 241-246; Parfit, On What Matters, 534-538; Huemer, "Revisionary Intuitionism"; James, An Introduction to Evolutionary Ethics, 79-81; Copp, "Darwinian Skepticism," 194; Street, "Darwinian Dilemma," 155. Such replies, while theism-compatible, are not uniquely theistic. 
There is a version of the Standard EDA that relies on each of the constraints on knowledge above, but I need not spell them out here. My point here is simply to show how the Standard EDA can be a vehicle for a variety of different epistemological objections and to set the stage for an explanation of how theists might reply to the Standard EDA. In extremely general terms, on the Standard EDA realists supposedly run afoul of each constraint because they think that the moral facts "float free" of our moral beliefs, whereas anti-realists think that there is a close dependence of the facts on our beliefs, allowing them to say that such beliefs are non-coincidentally true, formed on the basis of a non-accidentally reliable method, etc.

\section{The Natural Theistic Reply to the Standard EDA}

Many philosophers seem to think that, while the Standard EDA is at the very least prima facie problematic for the realist, it is clearly not problematic for the theistic moral realist. ${ }^{10}$ In most cases, this seems to be so clear to such philosophers that they relegate the point to a short paragraph, if not a footnote. Thus, Kahane:

If we were the designed products of God, then it does seem rational for us to rely on our natural doxastic dispositions given that these were implanted in us by an omniscient and omnibenevolent being. ${ }^{11}$

Bedke similarly claims:

Given this [our moral beliefs' causal history], it would be a great cosmic coincidence if the causal order were orchestrated just perfectly, so as to produce intuitions and beliefs that accurately reflect the ethical facts. We would need something like a god rigging the ethical facts and the causal order so as to ensure their serendipitous coincidence. ${ }^{12}$

The idea, I think, being that if we had evidence of such a god, the evolutionary objection from "cosmic coincidence" - in Bedke's terms-would disappear.

There are also those who claim that theism can easily solve a general epistemological objection. Parfit considers an argument from massive coincidence that is independent of evolutionary considerations and claims that:

God might have designed our brains so that, without such causal contact [with mathematical facts], we can reason in ways that lead us to reach true answers to mathematical questions. We might have similar God-given abilities to respond to reasons, and to form true beliefs about these reasons. ${ }^{13}$

\footnotetext{
${ }^{10}$ Besides those below, see Wielenberg, "Evolutionary Debunking," 460; Bogardus, "Only All Naturalists," 7, 12-13; Crow, "Plantingian Pickle," 10-11; and Fitzpatrick, "No Darwinian Dilemma," 250.

${ }^{11}$ Kahane, "Evolutionary Debunking Arguments," 109. See also n16, which acknowledges further complexities.

${ }^{12}$ Bedke, "Intuitive Non-Naturalism," 190.

${ }^{13}$ Parfit, On What Matters, 493.
} 
And likewise, in discussing the argument from non-accidental reliability mentioned above, Setiya claims that:

Things look different if we turn to God. Assuming God can know the truth in ethics, even if it is irreducible, he may create in us, or some of us, reliable dispositions. On this account, ethical principles can explain how we are disposed to form true beliefs [thus meeting the non-accidental reliability constraint]. This is, I think, the only hope for ethical knowledge if the facts are constitutively independent of us. ${ }^{14}$

So according to Setiya, not only can theism solve a major epistemological problem for realism, but it alone can.

However, things are not so easy for the theist as such philosophers have made them look. In fact, what's lacking from all of these philosophers' work is any real description of how the theistic response to the Standard EDA is supposed to work. In the rest of this section, I hope to give a plausible model for how a theistic reply to the Standard EDA would proceed. Only then can I point out the obstacles to such a reply.

First, we should get clear on the goal of theistic replies to the Standard EDA. Some of the quoted theistic replies above may be read as arguing that it is possible that realism is true, and we have moral knowledge. It is tempting to read them, that is, as arguing:

a. The evolutionary debunking argument fails in general, because it is possible that theism is true, and on theism, it's possible that moral realism is true and we have substantive moral knowledge.

(a) takes the task of debunking arguments to be to show the impossibility of moral knowledge. But this doesn't make sense of why such authors go on to present their own non-theistic proposals - why would they, if they had already defeated the Standard EDA?

My construal of debunking arguments makes sense of such reasoning: the Standard EDA is an argument that we don't have moral knowledge on realism, not that we can't. (Nor does it proceed to the former by way of the latter: surely the Empirical Premise is, if true, only contingently true.) So, the theist needs to do more than show the compossibility of (i) her brand of theism, ${ }^{15}$ (ii) moral realism, and (iii) our substantive moral knowledge. Yet she need not show that (iii) deductively follows from (i) and (ii), since she is only trying to rebut an argument that (ii) and (iii) don't co-obtain. So, the theist's task is to show, instead:

b. The Standard EDA fails for theists because, on the assumption of one's brand of theism, it's plausible - not merely possible - that if moral realism is true, then we have substantive moral knowledge.

\footnotetext{
${ }^{14}$ Setiya, Knowing Right from Wrong, 114.

${ }^{15}$ By one's "brand" of theism I mean simply theism, plus whatever claims one endorses about God that are not essential to theism per se.
} 
This means that, with a very important exception to be noted shortly, the theist is free to rely on any claim that is plausible on the assumption of her brand of theism to show that assuming (i) and (ii) makes (iii) plausible.

So, here's one example of how the theist could reply to the Standard EDA. Call it "the Natural Reply." God, if he exists, is omnipotent, omniscient, and morally perfect. Because he is omnipotent and omniscient, he has the ability to either (a) start the causal order in such a way that evolution results in human beings who have moral knowledge or (b) monitor the evolutionary process and intervene in the causal order to "tweak" that process if he foresees that it will lead to humans who don't have moral knowledge. ${ }^{16}$ The latter would be a form of "special divine action," which is assumed by some to be more problematic than other forms of God's action such as creating and sustaining the world. ${ }^{17}$ I will employ no such assumption here, ${ }^{18}$ but at any rate, if special divine action is especially problematic, (a) is still open for the theist.

To see how this would work in more detail, assume that the standard debunker supports (13) - the Epistemological Premise - via Sensitivity ${ }_{\text {EDA }}$. In either (a) or (b), we would end up with sensitive moral beliefs: in the nearest possible worlds in which our actual moral beliefs are false, God brings it about that we don't have them. (Of course, he could do (b) while also doing something akin to (a) - i.e., starting the causal order in such a way that, with the fewest possible "tweaks" on his part, it will result in humans with true moral beliefs.) And-very importantly-because God is morally perfect, he will do either (a) or (b). This is because a morally perfect being wants his creatures to be good, and goodness (at least for humans) requires moral knowledge. ${ }^{19}$

\section{A Challenge for the Natural Reply}

In this section, I will present a challenge for the Natural Reply. My argument relies on a controversial constraint on replies to the Standard EDA. I give an argument for that constraint, but in the end, I assume its truth for the sake of argument: if it is false, replies are incredibly cheap, and all realists - theists and non-theists - are in the clear. To be clear: I don't want to argue that the Natural Reply decisively fails. I mean just to use it as a specific model to show what I'll then argue is a much more general challenge for theistic replies.

The Natural Reply relies on the following claims: (i) a morally perfect being would want his creatures to be morally good, and (ii) moral goodness (at least for humans) requires moral knowledge (and hence, e.g., sensitive

\footnotetext{
${ }^{16}$ See Sober, "Evolution Without Naturalism" and Sober, "Evolutionary Theory, Causal Completeness, and Theism" for an argument that it is compatible with evolutionary theory that God guided certain mutations.

${ }^{17}$ See Plantinga, Where the Conflict Really Lies, ch. 3.

${ }^{18}$ See Plantinga, Where the Conflict Really Lies, chs. 3-4, for an argument that it is false.

${ }^{19}$ The Natural Reply might be thought problematic independently of its use as a reply to the Standard EDA. But such objections are not my concern here.
} 
moral beliefs). Each of these is plausibly a substantive moral claim; surely at least one is. But recall that the Standard EDA attempts to give decisive reason to think that it is precisely substantive moral claims that we can't know to be true. Surely we are unjustified in relying on a premise $P$ in an explanation if we have decisive reason to think that we don't know that P. (Imagine telling your friend that he shouldn't eat meat because it results in harm to animals but that you don't know that it results in harm to animals!) So, by relying on (i) and (ii) in her reply to the Standard EDA, the theist assumes that she does not have decisive reason to think that she doesn't know that those claims are true. But this is just to assume that the Standard EDA fails in the course of an argument that attempts to show that the Standard EDA fails.

The problem is going to be hard to get away from for the theist. He could easily fill in the details of his story differently: perhaps God wants us to have moral knowledge because a morally perfect being would want to maximize utility, and the best way for humans to maximize utility is by their having moral knowledge. (Again, there may be independent problems here.) But it's easy to see that this variation also relies on a substantive moral claim and will for that reason also beg the question against epistemological objections. Because the problem is so general, we can formulate it as a condition on any theistic reply to the epistemological objections in question:

(No Moral Claims) A reply to an epistemological objection to moral realism cannot rely on a substantive moral premise. ${ }^{20}$

(I will soon argue that No Moral Claims ought to be narrower, but this is the constraint as it is suggested in the literature.)

Let's say that a reply to an epistemological objection relies on a premise just when the content of that premise is part of the explanation of why we have moral knowledge. Importantly, a reply doesn't rely on a premise (in this restricted sense) when it merely enables the explanation of our moral knowledge. ${ }^{21}$ That I desired a Dr. Pepper might be part of the explanation of why I walked to the 7-Eleven. Yet, though I wouldn't have walked to the 7-Eleven had I desired much more strongly to stay home, that I didn't desire more strongly to stay home is not part of the explanation of my walking to 7-Eleven. It merely enables the explanation. In my sense then, the explanation of my walking to the 7-Eleven relies on the claim that I desired a Dr. Pepper, but not on the claim that I didn't desire more strongly to stay at home.

A brief word on the necessity of the distinction: lots of things are relevant, in some broad sense, to an explanation. It is in this broad sense that

\footnotetext{
${ }^{20}$ As I will construe it, No Moral Claims bans relying on substantive moral claims regardless of whether they are considered "part of" one's theistic position (as opposed to being an independent premise). Mutatis mutandis for all later modifications of No Moral Claims.

${ }^{21}$ See Dancy, Ethics Without Principles, ch. 3.
} 
both my desire for Dr. Pepper and my lack of overriding desire are relevant to my walking to the 7-Eleven. And it is in the same sense that it's relevant that I'm not asleep, and that I'm generally physically able to pursue the objects of my desires. But we don't want all of these things entering into the explanans-otherwise the explanans will be infinitely large! After all, there are infinitely many desires that I don't have but that (if I did have them) would override my present desire for a Dr. Pepper. So, we need some way of distinguishing those things that are relevant to the explanation, but which aren't themselves part of the explanans. And what seems to unite such things is that, either by their presence or absence, they allow the explanation to occur.

No Moral Claims only says that replies to epistemological objections to realism cannot rely on substantive moral claims and leaves open whether they can have substantive moral enabling conditions. The reason for the latter is that, if replies couldn't have substantive moral enabling conditions, it would be impossible to give a successful reply of any kind to the epistemological objection in question. For here is a condition without meeting which any such reply would fail: that there is a (morally) evil demon deceiving us about everything (or at least, everything it's possible for us to be deceived about). Were there such a demon, no exculpatory reply on behalf of our moral knowledge could succeed; yet the absence of such a demon seems not to be part of the explanans of how we have any given kind of knowledge, but rather to merely enable the explanation. Thus, any such reply, theistic or not, fails without the enabling condition that there is no such demon.

I think that, in light of that, No Moral Claims would be overbroad were it to outlaw substantive moral enabling conditions. But let me settle for establishing just this: were No Moral Claims to outlaw substantive moral enabling conditions, my project, as well as anyone else's who wants to reply to any epistemological objection to realism, would be doomed from the start (whether it relies on theism or not). So, I'll assume that No Moral Claims allows for substantive moral enabling conditions - i.e., it reads as I formulate it above-for the sake of argument.

There is a hardy debate about whether No Moral Claims is true. Many argue that it is. ${ }^{22}$ Many others argue that it is not, since in order to reply to skepticism in other domains-e.g., the perceptual-we must rely on substantive claims within that domain. ${ }^{23}$ I cannot settle the dispute here.

\footnotetext{
${ }^{22}$ See Shafer-Landau, "Evolutionary Debunking," 32-35; Horn, "Evolution and the Epistemological Challenge"; Behrends, "Meta-normative Realism," 7-8; Vavova, "Debunking Evolutionary Debunking," 81; Morton, "A New Evolutionary Debunking Argument"; and Morton, "When Do Replies."

${ }^{23}$ See Schafer, "Evolution and Normative Scepticism," 475-476; Shafer-Landau, "Evolutionary Debunking," 21-23; Enoch, Taking Morality Seriously, 175; Setiya, Knowing Right from Wrong, 79; White, "You Just Believe that Because . . .," sec. 4.2; Vavova, "Debunking Evolutionary Debunking," sec. 3.1; Berker, "Does Evolutionary Psychology," sec. 8; and Dogramaci, "Explaining Our Moral Reliability." See also Clarke-Doane, "Morality and Mathematics" and Bedke, "Intuitive Non-Naturalism," sec. 3.2, although these are more general over-generalization worries.
} 
I think No Moral Claims is plausible enough. But more importantly, as above, the question I'm concerned with here-whether theism is immune to epistemological objections to realism - is really only interesting on the assumption of No Moral Claims. If we can rely on substantive moral claims in replying to the Standard EDA, then replies are fairly cheap. ${ }^{24}$ David Enoch - and other proponents of "third-factor replies" - have shown how, on the assumption of just one substantive moral premise, it is no longer surprising that we ended up with true moral beliefs.

Enoch assumes that anything that promotes survival is at least somewhat good. If that's right, then when $\mathrm{X}$ promotes survival, $\mathrm{X}$ is good. But when $\mathrm{X}$ promotes survival, because of the evolutionary story, we should also not be surprised that we ended up believing that $X$ is good (it will make us more likely to pursue $\mathrm{X}$ ). This gives us an explanation of the striking correlation of our moral beliefs with the moral facts. ${ }^{25}$ This sort of reply could at the very least succeed against versions of the Standard EDA that identify the fundamental epistemological problem as one of accidental reliability or coincidental truth since, if we have an explanation of the correlation of our beliefs and their truth, their truth is not a coincidence, nor is our reliability accidental. And it may be harnessed as a reply to safety- and sensitivity-based worries (though I cannot pursue this question here). So, I will assume No Moral Claims because our question here is only of interest if it is true.

The Natural Reply, though it does seem to rely on substantive moral claims, is not necessarily doomed. As I'll argue in section 5, relying on substantive moral claims is not automatically a problem: just when they are constitutively independent of any agent's attitudes. I'll leave open (for now) whether the Natural Reply has the resources to maintain that each of the substantive moral claims it relies on are not mind-independent in this way. So, let the content of this section stand as a defeasible worry for the Natural Reply.

\section{A Challenge for Any Theistic Reply}

But No Moral Claims isn't just a problem for the Natural reply. In this section, I'll issue a challenge to any theistic reply to the Standard EDA: the theist needs to avoid appealing to a substantive moral claim in the course of what I'll argue is her best line of response to the Standard EDA. I think that the theist can answer the challenge. It's just that answering the challenge turns the theistic reply into something far different than the Natural Reply.

The theist's job, in giving a distinctly theistic reply to the Standard EDA, is to show that, on the assumption of her brand of theism, the following claim is true:

\footnotetext{
${ }^{24}$ Enoch, Taking Morality Seriously, ch. 7; Schafer, "Evolution and Normative Scepticism," 477; Wielenberg, "Evolutionary Debunking"; Brosnan, "Do the Evolutionary Origins"; Skarsaune, "Darwin and Moral Realism"; Parfit, On What Matters, 532-533; Setiya, Knowing Right from Wrong, ch. 2; and Dworkin, "Objectivity and Truth," 125.

${ }^{25}$ See Enoch, Taking Morality Seriously, 7.4.
} 
(Divine Action) God has intentionally acted so as to bring about (or make likely) our moral knowledge.

Of course, there are logically possible alternatives here, which still make appeal to God. Perhaps, for example, God unintentionally brought about our moral knowledge. But these alternatives seem so implausible that the theist, in appealing to them, would no longer have a minimally plausible response to the Standard EDA. So, since theism doesn't on its own entail Divine Action, the theist must convince us that we get Divine Action on the assumption that her brand of theism is true.

Here's what I consider a very natural way of doing this. When an omniscient, perfectly rational being - which the God of theism is-has most overall normative reason (henceforth "reason") to do something, he will do that thing. (Aquinas endorses a similar, though weaker thesis-but about the good rather than normative reasons - when he claims that the "voluntary appetite tends to a good which is apprehended." ${ }^{26}$ ) One argument for this runs as follows. Assuming a minimal type of motivational internalism, according to which a perfect being's motives are in proportion to his beliefs about his reasons, and that a perfect being would be omniscient, it follows that a perfect being's motives are in proportion to his reasons. If perfect beings cannot experience weakness of will, then a perfect being will always do what he has most overall reason to do. ${ }^{27}$

So, the theist should argue that God at some point had most overall reason to bring about our moral knowledge. This would ideally involve two separate arguments: an argument that God had reason to bring about our moral knowledge, and an argument that this reason was not outweighed by any other reasons God had at the time. (That God has reasons - even moral reasons - to act doesn't, of course, commit us to the controversial claim that God has moral obligations since God could have a (moral) reason to $\Phi$ without having an obligation to $\Phi .^{28}$ )

Unfortunately, the second task is a huge one. But I take it as prima facie plausible that the God of theism wouldn't have strong reason to do anything incompatible with our moral knowledge-at least, such reason wouldn't be strong enough to outweigh his reason to bring about our moral knowledge. (If I am wrong about this, then we were all silly to assume that the theist could ever have a response to the Standard EDA: God would not have ever brought about our moral knowledge!) Importantly, accounts that require this stipulation won't, just in virtue of this, violate No Moral Claims. That there are no counter-balancing reasons for God not to bring about our moral knowledge merely enables, but does not explain,

\footnotetext{
${ }^{26}$ See Aquinas, Summa Theologica IaIIae, Q. 8. See also Leftow, "Aquinas on God and Moral Truth."

${ }^{27}$ See Murphy, God's Own Ethics, 27-28; Murphy, "Is an Absolutely Perfect Being Morally Perfect?"; and Swinburne, Coherence of Theism, 184-209.

${ }^{28}$ See Alston, "Some Suggestions for Divine Command Theorists" for an argument that God has no moral obligations.
} 
why God would bring about our moral knowledge. Rather, God's reasons explain why he would so act. Thus, a response that requires that God not have counter-balancing reason not to bring about our moral knowledge doesn't rely on this claim, in the technical sense I use here, and so such a response won't violate No Moral Claims. So, I will assume here that if the theist has shown that God at some point had reason to bring about our moral knowledge, he has thereby shown that Divine Action is true.

It's important to see that this is just as much a challenge for theistic replies to any of the epistemological objections that I have mentioned. Recall that they all share the same conclusion: if moral realism is true, then no agent has any substantive moral knowledge. So, if theistic responses to the Standard EDA require the theist to show Divine Action, then likewise for the other objections. In each case, the theist needs to show the same thing: that God intentionally brought about our moral knowledge. In order to reply to any of the objections I've mentioned, the theist must argue for Divine Action without appealing to substantive moral claims.

\section{Hope for the Theistic Moral Realist}

Thus far, I have played the pessimist. I have issued a challenge that, if unanswered, entails that theists are not in any privileged position with regard to answering epistemological objections to moral realism. But in this section of the paper, I want to explore whether the theist can answer this challenge. I will outline and evaluate two ways in which the theist could reply to the Standard EDA - and thus the other epistemological objections mentioned here-without violating No Moral Claims (or rather, the condition as it ought to be formulated, which I am about to lay out). I conclude that the theist actually can successfully reply to epistemological objections to moral realism, in a way that non-theists cannot.

First let me canvas a type of reply I won't be giving but to which I see no in-principle barrier. This kind of reply appeals to divine revelation that has as its content moral truth. As Tomas Bogardus argues, this could be in a number of ways. ${ }^{29}$ Among them: divinely-inspired Scripture, the inner testimony of the Holy Spirit, etc. Such replies need not rely on any kind of moral claim-God speaks, and we listen.

I won't argue against such replies here. But I intend to give a different kind of reply, one more in line with both the spirit of the Natural Reply, as well as the comments I canvassed earlier, from Kahane, Bedke, Parfit, and Setiya. ${ }^{30}$ The idea behind those authors' comments, which I tried to exemplify in the Natural Reply, was to avoid appealing to divine revelation to supply the content of moral truth. Rather, these views attempt to give theistic accounts of moral knowledge which do not depend on the knower recognizing the authority of divine testimony. Yet I argue we can

\footnotetext{
${ }^{29}$ Bogardus, "Only All Naturalists."

${ }^{30} \mathrm{I}$ do, however, allow for theists to appeal to revelation of claims that do not run afoul of No Moral Claims (as it will presently be modified).
} 
still avoid violating No Moral Claims (at least in reformulated form, which I'll give shortly).

The appeal of this sort of reply is at least threefold. First, it's interesting in its own right to have a distinct kind of reply from revelation-based replies. Second, my reply will be compatible with a broad range of theistic positions that the revelation-based replies will not. Revelation-based replies don't come incredibly cheaply: God must have revealed just the right moral truths, with a fairly high clarity and lack of ambiguity, in order for this gambit to work. Views on which God has revealed only some relatively peripheral moral truths, or on which we can't be too sure how to interpret the moral claims God has made-the list could go on-will not be able to save moral knowledge. Many theists will therefore not be in a position to make use of revelation-based replies; a non-revelation-based theistic reply will be of interest to them. Finally, and perhaps most saliently, revelation-based replies seem to require the knower to recognize the authority of divine testimony-why else trust the Scriptures, or the testimony of the Spirit? Such accounts will have a hard time allowing for the moral knowledge of (at least) those who reject the existence of God. On the other hand, if replies like mine work, theism saves the possibility of moral knowledge in general-even for non-theists.

It's very important to see that No Moral Claims is too broad a restriction, as stated. Recall the dialectic: debunkers argue that what causes problems for our moral knowledge is the claim that some moral truths are constitutively independent of anyone's attitudes. What motivates No Moral Claims is the idea that, when a realist relies on a moral claim in her response to the Standard EDA, she's relying on exactly the kind of claim knowledge of which the debunker is targeting. So, it seems that No Moral Claims ought to be restricted:

(No Moral Claims*) A reply to an epistemological objection to moral realism cannot rely on a substantive moral premise that, if true, is true independent of anyone's attitudes.

Since it is only attitude-independent moral claims that the Standard EDA targets, surely it should only be such claims that are off-limits in replying to the Standard EDA.

So, the moral realist needs to establish that God has a reason to bring about our moral knowledge without relying on any claim that is both a substantive moral claim and attitude-independent if true. In the remainder of this section, I first want to show two ways that the theist could do this. In the next section, I'll show why the same general strategy works even for normative realists replying to epistemological worries for normative realism.

The key insight in the theistic realist's response is that moral realists need not think that all moral truths are attitude-independent. This follows from realism as I defined it above-it claims only that some moral truths are mind-independent, not that all are. Of course, the question is whether 
this is the right way of characterizing the debate. For in reality there are three salient positions: that no moral truths are mind-independent, that some are, and that all are. I believe the middle claim is the important claim for the realist. Not only is this often how the debate is characterized ${ }^{31}-$ especially within the debunking literature ${ }^{32}-$ but the interesting question seems to be whether there exist any truths of a certain kind (mind-independent moral truths), not so much whether all moral truths are like this. ${ }^{33}$ At any rate, this is the kind of realism I am concerned with here. So, we need not worry about whether any given normative claim that the theist relies on is a substantive moral claim so long as that claim is one such that, if true, its truth is fully explained by some agent's (or agents') attitudes.

God, of course, has attitudes, and there doesn't seem to be any barrier to those attitudes explaining his reasons, just as our attitudes often explain our reasons. The task for the theistic moral realist is to find an attitude that God plausibly has that could fully explain his reason to bring about our moral knowledge. The theist must, however, do this in a way that doesn't invite further questions about why God has that attitude. Otherwise, it might be that while God's reason is grounded in an attitude, he only holds that attitude because some mind-independent, substantive moral claim is true, such that the attitude is explained by the mind-independent moral truth. Then the theist's story would still violate No Moral Claims*. So, what we want is a reason that is fully explained by attitudes, where these attitudes are not explained by any further mind-independent, substantive moral truths. ${ }^{34}$

Suppose, then, that God wants us to have moral knowledge because it will be good for us. He wants what is good for us simply because he loves us - and that seems like as good a place as any to end an explanation. Thus, God's reason to bring about our moral knowledge is satisfactorily explained-in a way that does not demand further explanation-by his love for us. This reason is thus explained by someone's attitudes-i.e., God's - and so the theist does not violate No Moral Claims* in relying on the claim that it obtains.

But why think that moral knowledge will be good for us? Because it makes us resemble God more, no matter what the moral truths are, and it is good for us to resemble God. First, since God knows the moral truths (because he knows everything), our knowing them makes us more like him. Second, moral knowledge will help us to do what we have moral reason to do, regardless of what that is, since we are much more likely to do what we have moral reason to do if we know what that is. To the extent

\footnotetext{
${ }^{31}$ E.g., Enoch, Taking Morality Seriously.

${ }^{32}$ E.g., Street, “Darwinian Dilemma," 110.

${ }^{33}$ In addition, this keeps the realism/antirealism debate analogous to the externalism/ internalism debate about reasons. See Finlay and Schroeder, "Reasons for Action."

${ }^{34} \mathrm{~A}$ referee worries that, for any reason which I propose is fully explained by an attitude, it will in fact only be partially explained by that attitude and will require mind-independent, substantive moral truths to complete that explanation. I think this line of thinking is only
} 
that we do what we have moral reason to do, we more closely resemble God since God does what he has moral reason to do.

As Robert Adams has pointed out, the notion of resemblance presents some peculiar problems. ${ }^{35} \mathrm{It}^{\prime} \mathrm{s}$ not clear what resemblance is for one thing, since merely sharing a property is not enough: a squirrel could have the same number of hairs as me and not resemble me any more than an otherwise identical squirrel. Furthermore, merely resembling God is not sufficient for goodness: parodies resemble their objects but do not share in their virtues. (Though Adams is concerned with goodness rather than the good-for relation, we might have a related worry about the latter: I may parody God, and thus resemble him, and be worse-off for it.)

I can only dip into such deep waters here, but it is worth noting that while our theistic realist will eventually want to flesh out her theory of resemblance, the issue doesn't present the problems it does for Adams and so is not nearly so pressing. Adams is so worried about the above worries in large part because he needs to make sure to give a realistic account of resemblance-one on which the fact that two things resemble each other obtains mind-independently. He has to worry about this because on his view, all goodness is grounded in resembling God, such that an anti-realistic understanding of resemblance would result in thorough-going anti-realism about the good, which he wants to avoid..$^{36}$ But our theistic moral realist is not committed to the claim that goodness is always grounded in resembling God-just that this is sometimes the case. And, so, even if resemblance-or the conditions under which resemblance to God is good for someone-is mind-dependent, this would only commit us to the claim that well-being is sometimes mind-dependent. And that is consistent with realism as I've defined it-even realism about well-being in particular.

Now, it might be objected that my explanation above appeals to substantive moral claims. After all, I said that (i) God knows the moral truth, that (ii) God does what he has moral reason to do, that (iii) knowing the moral truth will help us do what we have moral reason to do, and that (because of all this) (iv) we resemble God insofar as we have moral knowledge. Are none of (i-iv) substantive, mind-independent moral claims? After all, they each use the word "moral," variously making claims about moral knowledge, moral truth, and moral reasons.

We saw above that (iv) might be mind-dependent and the theistic realist can consistently endorse this. But that won't help with (i)-(iii). So, I will argue that the theist avoids violating No Moral Claims* here because none of (i)-(iv) is a substantive moral claim. As I noted above, defining "substantive moral claim" is very hard, and I argued that we only need a non-definitional characterization of such claims: they're the set of claims

plausible if we assume that all moral truths are mind-independent-and I have argued that realists are not committed to this.

${ }^{35}$ Adams, Finite and Infinite Goods, 31-33.

${ }^{36}$ Adams, Finite and Infinite Goods, 18. 
knowledge of which debunkers are targeting. While I don't intend to give a definition of "substantive moral claim," I think the following is a good test, at least for claims that do not represent principles: a claim is a substantive moral claim only if its truth value changes depending on what we have moral reason to do. ${ }^{37}$ But (i)-(iv) will be true regardless of what anyone has moral reason to do.

Consider (i): God, because he knows everything, knows the moral truth regardless of what moral reasons obtain or fail to obtain. If rational beings have moral reason to maximize utility, then he knows this. If rational beings have no such reason, he knows this. Now consider (ii): whether God has moral reason to deceive or refrain from deception, to kill or refrain from killing, he will still do what he has moral reason to do. Similarly, for (iii): whether we have moral reason to lie or not (etc.), knowing the moral truth will help us do what we have moral reason to do. And finally, consider (iv): because of the foregoing, we resemble God insofar as we have moral knowledge, regardless of what anyone has moral reason to do. ${ }^{38}$

Before I move on to consider a second strategy for the theistic realist, let's consider a second objection: this first strategy relies on claims about well-being, or the good-for relation. Is well-being a moral phenomenon? If so, then insofar as such truths are attitude-independent, the theist cannot rely on substantive claims about well-being, such as that it is good for us to resemble God.

The theist might try replying that the good-for relation is non-moral. I think this is right, but for reasons that will soon become clear, this won't help the cause. The theist ought instead to argue that the claims about well-being required to make his case are not true independent of anyone's attitudes. Having desires satisfied, experiencing pleasure, being happy: all of these states can fully explain an increase in well-being, without conflicting with moral realism, as explained above. Not only that, such explanations are compatible even with objectivist theories of well-being since objectivist theories allow that sometimes having a desire satisfied (etc.) is a benefit.

And it's easy to make the case that moral knowledge will promote such states without relying on any substantive moral claims: we will be happy/ have more desires filled/experience more pleasure insofar as we resemble God, regardless of what anyone has moral reason to do. These claims are

\footnotetext{
${ }^{37}$ As I note in the main text, moral principles are an exception: they are often substantive, while being compatible with the obtaining of any moral reasons. "If punching John shortens his life, then we have moral reason to refrain from punching him" is technically compatible with both having moral reason to refrain from punching John and not having such reason (after all, the conditional is compatible with the falsity of the antecedent). But we can brush aside such examples here since we're not aiming for a sure-fire test for some claim's being a substantive moral one. The test seems like a good one for claims like (i)-(iv).

${ }^{38}$ One might think there is cause for worry here if Robert Adams is right that for any non-supreme good, $X$ is good because $X$ resembles God, the supreme Good (see Adams, Finite and Infinite Goods, ch. 1). But even if this is true, claims about resemblance to God need not be substantive moral claims. That goodness is fully grounded in property $\mathrm{P}$ does not entail that claims about $\mathrm{P}$ are moral claims. The hedonistic utilitarian need not say that claims about pain and pleasure are moral claims, after all.
} 
generally plausible on the assumption of most theistic views: does God want us to resemble him even though it won't make us happier, or fulfill any of our desires? No-promotion of such states seems like one of the main reasons he would desire that we resemble him.

A second general route for the theistic moral realist also appeals to the claim that we resemble God insofar as we have moral knowledge and helps itself to claims (i)-(iv) above in order to establish that. But instead of arguing that it is good for us that we resemble God, the theist could here argue that God desires his own glorification, and he doesn't desire this for any further reason - he just desires it. ${ }^{39}$ Furthermore, the theist could argue, it glorifies God to have his creation resemble him. Therefore, God's desire for his own glorification grounds a reason to bring about our moral knowledge.

It seems perfectly in line with many theistic pictures to say that God desires his own glorification. Furthermore, this is consistent with God being perfectly well-off since it seems possible for a perfectly well-off being to have desires. (At any rate, the theist is in much deeper trouble if God has no desires: it is a common assumption among theists that there are things God wants us to do.) And of course, if God's reason to bring about our moral knowledge is explained by his desire for glorification, the theist won't here run afoul of No Moral Claims*.

Some pieces of the above argument appeal to claims tenable on any version of theism. The argument that we resemble God insofar as we possess moral knowledge appeals only to such claims-(i)-(iv) should be tenable on any brand of theism (or, at least, any brand compatible with moral realism). Yet both replies appeal also to claims that are not part and parcel of theism per se. The first reply claims that God loves us and that resembling God is good for us. The second claims that God desires his own glorification, and that it glorifies God when his creation resembles him. Of these four claims, none seems entailed by theism per se. But it seems to me that many brands of theism will accept either the first two or the second two. And those are the brands of theism that, for all I've argued, are in a good position to give replies to epistemological objections to moral realism.

\section{Epistemological Objections to Normative Realism}

What I have called the Standard EDA targets moral realism. Yet many epistemological objections, such as Street's, have it that if normative realism is true, then we have no normative knowledge. ${ }^{40}$ (Normative realism is the thesis that (i) sincere normative judgments express beliefs, (ii) some of those beliefs are true, and (iii) the truth of some normative beliefs does not constitutively depend on the attitude of any actual or hypothetical agent.) This begets the worry that an analogue of No Moral Claims holds:

\footnotetext{
${ }^{39}$ This is a weakness of the second strategy that the first does not have: God may only desire his own glorification because it is good (or because he has reason to, etc.) such that his glory-based reason is not ultimately explained merely in terms of his attitudes. In that case, the theist may have to appeal to a mind-independent moral claim, thus violating No Moral Claims*.

${ }^{40}$ Street, "Darwinian Dilemma."
} 
(No Normative Claims) A reply to an epistemological objection to normative realism cannot rely on a substantive normative premise.

And this is worrisome for the theist in particular because both of the theistic responses I proposed to the Standard EDA rely on substantive normative premises.

However, just as with the Standard EDA, I think that No Normative Claims is over-broad. Normative realism allows that some reasons are explained by our attitudes: in Mark Schroeder's example, Ronnie likes dancing and Bradley doesn't, and that is enough to explain why Ronnie has a reason to go to the party but Bradley doesn't. ${ }^{41}$ Again, this is allowed by my definition of normative realism, and there is again reason to think the important debate is whether there are any normative truths that are mind-independent. As Schroeder notes, realists of any stripe should agree that some reasons are explained by our attitudes in this way. ${ }^{42}$ Schroeder's Humean Theory of Reasons is the further, controversial claim that all reasons are so explained.

So just as in the moral case, we ought to reformulate our constraint:

(No Normative Claims*) A reply to an epistemological objection to normative realism cannot rely on a substantive normative premise that, if true, is true independent of anyone's attitudes.

Because he doesn't violate this suitably qualified constraint, the theist can now simply import his two responses to the Standard EDA, suitably modified. We resemble God insofar as we have any kind of knowledge, after all, or insofar as we are disposed to act in accordance with any kind of reason. So, whether God's reason springs from his desire for our wellbeing or his desire for glorification, he will have a reason to bring about all normative knowledge in us.

\section{Conclusion}

Many philosophers take it as a truism that theists need not worry at all over various epistemological objections to moral realism: if God exists, certainly he could just engineer things in such a way that we end up with moral knowledge. But the most natural ways of arguing for this are stripped from us when we recognize that we cannot rely on any mind-independent substantive moral claims. However, there is hope for the theist: God plausibly has mind-dependent reasons to bring about our moral knowledge. If so, then the theist can reply to epistemological objections to moral realism without begging the question. Not only that, but she can reply to epistemological objections to normative realism without begging the question. The upshot here is nothing so grand as that moral/normative realists ought to be theists. However, it might be as significant as that

\footnotetext{
${ }^{41}$ Schroeder, Slaves of the Passions, 1.

${ }^{42}$ Schroeder, Slaves of the Passions, 1-2.
} 
theists are better off with respect to epistemological objections to moral/ normative realism than are non-theists. To the extent that such objections succeed, non-theistic realism fails while theistic realism lives to fight another day. ${ }^{43}$

University of California, Davis

\section{References}

Adams, Robert. 1999. Finite and Infinite Goods (Oxford University Press).

Alston, William. 1990. "Some Suggestions for Divine Command Theorists." In Christian Theism and the Problems of Philosophy, edited by Michael Beaty (University of Notre Dame Press), 303-326.

Aquinas, St. Thomas. (1485) 1948. Summa Theologica (Benziger Brothers).

Bedke, Matthew. 2009. "Intuitive Non-Naturalism Meets Cosmic Coincidence." Pacific Philosophical Quarterly 90: 188-209. https://doi.org/10.1111/j.1468-0114.2009.01336.x

Behrends, Jeff. 2013. "Meta-normative Realism, Evolution, and Our Reasons to Survive." Pacific Philosophical Quarterly 94: 486-502.

https://doi.org/10.1111/papq.12010

Berker, Selim. 2014. "Does Evolutionary Psychology Show That Normativity is Mind-Dependent?" In Moral Psychology and Human Agency: Philosophical Essays on the Science of Ethics, edited by Justin D'Arms and Daniel Jacobson (Oxford University Press), 215-252. https://doi.org/10.1093/acprof:oso/9780198717812.003.0010

Bogardus, Tomas. 2016. "Only All Naturalists Should Worry About Only One Evolutionary Debunking Argument." Ethics 126: 636-661.

https://doi.org/10.1086/684711

Brosnan, Kevin. 2011. “Do the Evolutionary Origins of Our Moral Beliefs Undermine Moral Knowledge?" Biology and Philosophy 26: 51-64. https://doi.org/10.1007/s10539-010-9235-1

Clarke-Doane, Justin. 2012. "Morality and Mathematics: The Evolutionary Challenge." Ethics 122: 313-340. https://doi.org/10.1086/663231

Copp, David. 2008. "Darwinian Skepticism About Moral Realism." Philosophical Issues 18: 186-206. https://doi.org/10.1111/j.1533-6077.2008.00144.x

Crow, Daniel. 2016. "A Plantingian Pickle for a Darwinian Dilemma: Evolutionary Arguments Against Atheism and Normative Realism." Ratio 29: 130-148. https://doi.org/10.1111/rati.12092

Dancy, Jonathan. 2004. Ethics Without Principles (Oxford University Press). https://doi.org/10.1093/0199270023.001.0001

Darwin, Charles. (1871) 1998. The Descent of Man (Prometheus).

Dogramaci, Sinan. 2016. "Explaining Our Moral Reliability." Pacific Philosophical Quarterly 97: 1-16. https://doi.org/10.1111/papq.12153

\footnotetext{
${ }^{43}$ For generous feedback, I would like to thank Dan Bonevac, Jonathan Dancy, Alex Hyun, Eric Sampson, and all the audience members at both the 2018 Alabama Philosophical Society meeting and the 2016 Midwest Society of Christian Philosophers meeting.
} 
Dworkin, Ronald. 1996. “Objectivity and Truth: You'd Better Believe It.” Philosophy and Public Affairs 25: 87-139. https://doi.org/10.1111/j.1088-4963.1996.tb00036.x

Enoch, David. 2011. Taking Morality Seriously (Oxford University Press). https://doi.org/10.1093/acprof:oso/9780199579969.001.0001

Finlay, Stephen, and Mark Schroeder. 2017. "Reasons for Action: Internal vs. External." In the Stanford Encyclopedia of Philosophy, edited by Edward Zalta (Fall 2017 edition). https://plato.stanford.edu/archives/fall2017/entries/reasonsinternal-external/.

Fitzpatrick, William. 2014. "Why There is No Darwinian Dilemma for Ethical Realism." In Challenges to Moral and Religious Belief, edited by Michael Bergmann and Patrick Kain (Oxford University Press), 237-255.

https://doi.org/10.1093/acprof:oso/9780199669776.003.0013

Gibbard, Allan. 2003. Thinking How to Live (Harvard University Press).

Greene, Joshua. 2008. “The Secret Joke of Kant's Soul.” In Moral Psychology, Vol. 3: The Neuroscience of Morality, Emotions, Brain Disorders and Development, edited by Walter Sinnott-Armstrong (MIT Press), 35-80.

Horn, Justin. 2017. "Evolution and the Epistemological Challenge to Moral Realism." In The Cambridge Companion to Evolutionary Ethics, edited by Michael Ruse and Robert Richards (Cambridge University Press), 114-128. https://doi.org/10.1017/9781316459409.009

Huemer, Michael. 2008. "Revisionary Intuitionism." Social Philosophy and Policy 25: 368-392. https://doi.org/10.1017/S026505250808014X

James, Scott. 2011. An Introduction to Evolutionary Ethics (Wiley-Blackwell).

Joyce, Richard. 2001. The Myth of Morality (Cambridge University Press). https://doi.org/10.1017/CBO9780511487101

Joyce, Richard. 2007. The Evolution of Morality (MIT Press). https://doi.org/10.1093/acprof:oso/9780195310139.003.0016

Kahane, Guy. 2011. “Evolutionary Debunking Arguments.” Nous 45: 103-125. https://doi.org/10.1111/j.1468-0068.2010.00770.x

Kitcher, Philip. 2007. “Biology and Ethics.” In The Oxford Handbook of Ethical Theory, edited by David Copp (Oxford University Press), 163-185.

https://doi.org/10.1093/0195147790.003.0007

Leftow, Brian. 2005. “Aquinas on God and Modal Truth." The Modern Schoolman 82: 171-200. https://doi.org/10.5840/schoolman20058237

Morton, Justin. 2016. “A New Evolutionary Debunking Argument Against Moral Realism." The Journal of the American Philosophical Association 2: 233-253. https://doi.org/10.1017/apa.2016.14

Morton, Justin. 2019. "When Do Replies to the Evolutionary Debunking Argument Against Moral Realism Beg the Question?" Australasian Journal of Philosophy 97: 265-280. https://doi.org/10.1080/00048402.2018.1455718

Murphy, Mark C. 2019a. God's Own Ethics: Norms of Divine Agency and the Argument from Evil (Oxford University Press).

Murphy, Mark C. 2019b. “Is an Absolutely Perfect Being Morally Perfect?” In Current Controversies in Philosophy of Religion, edited by Paul Draper (Routledge), 93-108. https://doi.org/10.4324/9781315645681-6 
Parfit, Derek. 2011. On What Matters (Oxford University Press). https://doi.org/10.1093/acprof:osobl/9780199572816.001.0001

Plantinga, Alvin. 2011. Where the Conflict Really Lies: Science, Religion, and Naturalism (Oxford University Press).

https://doi.org/10.1093/acprof:oso/9780199812097.001.0001

Pritchard, Duncan. 2008. "Sensitivity, Safety, and Anti-Luck Epistemology." In The Oxford Handbook of Skepticism, edited by John Greco (Oxford University Press), 437-455. https://doi.org/10.1093/oxfordhb/9780195183214.003.0021

Ruse, Michael, and E. O. Wilson. 1985. "The Evolution of Ethics." New Scientist 108: 50-52.

Ruse, Michael, and E. O. Wilson. 1986. "Moral Philosophy as Applied Science." Philosophy 61: 173-192. https://doi.org/10.1017/S0031819100021057

Schafer, Karl. 2010. "Evolution and Normative Scepticism." Australasian Journal of Philosophy 88: 471-488. https://doi.org/10.1080/00048400903114219

Schroeder, Mark. 2007. Slaves of the Passions (Oxford University Press). https://doi.org/10.1093/acprof:oso/9780199299508.001.0001

Setiya, Kieran. 2012. Knowing Right From Wrong (Oxford University Press). https://doi.org/10.1093/acprof:oso/9780199657452.001.0001

Shafer-Landau, Russ. 2012. “Evolutionary Debunking, Moral Realism and Moral Knowledge." Journal of Ethics and Social Philosophy 7: 1-37.

https://doi.org/10.26556/jesp.v7i1.68

Skarsaune, Knut. 2011. "Darwin and Moral Realism: Survival of the Iffiest." Philosophical Studies 152: 229-243. https://doi.org/10.1007/s11098-009-9473-8

Sober, Elliott. 2010. "Evolution Without Naturalism." In Oxford Studies in Philosophy of Religion, vol. 3, edited by Jonathan Kvanvig (Oxford University Press), 187-221. https://doi.org/10.1093/acprof:oso/9780199603213.003.0010

Sober, Elliott. 2014. "Evolutionary Theory, Causal Completeness, and Theism: the Case of 'Guided' Mutation." In Evolutionary Biology-Conceptual, Ethical, and Religious Issues, edited by Denis Walsh and Paul Thompson (Cambridge University Press), 31-44. https://doi.org/10.1017/CBO9781139208796.004

Street, Sharon. 2006. "A Darwinian Dilemma for Realist Theories of Value." Philosophical Studies 127: 109-166. https://doi.org/10.1007/s11098-005-1726-6

Street, Sharon. 2008. "Reply to Copp: Naturalism, Normativity, and the Varieties of Realism Worth Worrying About." Philosophical Issues 18: 207-228. https://doi.org/10.1111/j.1533-6077.2008.00145.x

Swinburne, Richard. 1993. The Coherence of Theism (Oxford University Press). https://doi.org/10.1093/0198240708.001.0001

Unger, Peter. 1968. "An Analysis of Factual Knowledge." Journal of Philosophy 65: 157-170. https://doi.org/10.2307/2024203

Vavova, Katia. 2014. "Debunking Evolutionary Debunking." In Oxford Studies in Metaethics, vol. 9, edited by Russ Shafer-Landau (Oxford University Press), 76-101. https://doi.org/10.1093/acprof:oso/9780198709299.003.0004

White, Roger. 2010. "You Just Believe That Because . . ." Philosophical Perspectives 24: 573-615. https://doi.org/10.1111/j.1520-8583.2010.00204.x

Wielenberg, Erik. 2010. "On the Evolutionary Debunking of Morality." Ethics 120: 441-464. https://doi.org/10.1086/652292 